\title{
Biosorption of chromium(VI) from aqueous solutions using waste plant biomass
}

\author{
A. Mishra $\cdot$ A. Dubey $\cdot$ S. Shinghal
}

Received: 13 September 2012/Revised: 26 August 2013/Accepted: 11 January 2014/Published online: 4 February 2014

(C) Islamic Azad University (IAU) 2014

\begin{abstract}
Metal biosorption on plant-based materials and agricultural wastes is a well practiced but a complex process affected by several factors. The biosorption of chromium(VI) from aqueous solution onto waste plant biomass of Portulaca Oleracea was studied in the present work. Batch studies were carried out to examine the effects of process parameters. Influence of altering various process parameters was studied. The biosorption process was fast, and equilibrium was achieved in $45 \mathrm{~min}$ of contact time. It was found that the biosorption capacity of plant material depends on many factors mainly on solution $\mathrm{pH}$, with a maximum biosorption capacity for chromium at $\mathrm{pH}$ 2. The biosorption kinetics was tested with pseudofirst-order and pseudo-second-order reaction, and results showed that biosorption followed pseudo-second-order rate expression. Experimental equilibrium data were applied to two different isotherm models. Isotherm tests showed that equilibrium sorption data were better represented by Langmuir model, and the sorption capacity of plant biomass was found to be $54.945 \mathrm{mg} / \mathrm{g}$. Thermodynamic parameters like $\Delta G^{0}, \Delta H^{0}$ and $\Delta S^{0}$ were also
\end{abstract}

A. Mishra

Department of Applied Chemistry, Gautam Buddha University, G B Nagar 201306, India

A. Dubey $(\bowtie)$

Reader Department of Chemistry, MMH College, Affiliated to CCS University, Ghaziabad, Meerut 201009, India

e-mail: abhaadubey@gmail.com

S. Shinghal

Department of Applied Sciences, AKG Engineering College, Affiliated to Mahamaya Technical University, Ghaziabad, Noida 201009, India evaluated, and it was found that the biosorption was spontaneous and endothermic in nature. Plant biomass was found to be an effective adsorbent for chromium(VI) from aqueous solution. This study indicated that plant biomass could be used as an efficient, cost-effective and environmentally safe biosorbent for the treatment of chromium containing aqueous solutions.

Keywords Isotherms - Portulaca oleracea . Pseudo-second-order equation - Thermodynamics

\section{Introduction}

Aquatic environment is under formidable impending danger of being substantially ravaged because of unplanned industrialization and urbanization. Uncontrolled and untreated industrial discharges are often laden with highly toxic quantities of heavy metals. The heavy metals are of specific concern due to their toxicity, persistency and bioaccumulating tendencies. Heavy metals especially those accumulated within the living organisms as well as in human body are dangerously toxic and environmentally harmful substances (Aksu and Akpinar 2001). These metals have attracted much concern in recent years (Baniamerian et al. 2009). Among these heavy metals, chromium $(\mathrm{Cr})$ is one of the priority pollutants in surface water and groundwater. World Health Organization (WHO) has determined chromium as a human carcinogen (Sheng et al. 2004) and is widely recognized to exert toxic effects in its hexavalent form (Rowbotham et al. 2000). The Agency for Toxic Substances and Disease Registry (ATSDR) classifies $\mathrm{Cr}(\mathrm{VI})$ as the top sixteenth hazardous substance.

Chromium exists in trivalent and hexavalent forms in aquatic system; all other oxidation states are unstable. The 
trivalent form is an essential nutrient, while hexavalent form is widely recognized to exert toxic effects. Chromium(III) is an essential trace element in mammalian metabolism. In addition to insulin, it is responsible for reducing blood glucose levels and is used to control certain cases of diabetes. It has also been found to reduce blood cholesterol levels by diminishing the concentration of (bad) low-density lipoproteins "LDLs" in the blood. $\mathrm{Cr}(\mathrm{III})$ is supplied in a variety of foods such as Brewer's yeast, liver, cheese, whole grain breads and cereals, and broccoli. Hexavalent form is 500 times more toxic than trivalent form and has higher mobility and solubility in water. It is highly mobile in soil and aquatic system and is a strong oxidant capable of being absorbed by the skin. Chromium(VI) has received widespread attention and classified as a high-priority toxic pollutant due to its high solubility in water (Raji and Anirudhan 1998; Costa 2003). This metal is used in a number of metal plating, nuclear industries including leather tanning power plants, textile industry, water cooling, pigment manufacturing, wood preservatives and mining operations.

The chromium affects human physiology by accumulating in food chain and cause several ailments (Park and Jung 2001). Human exposure to $\mathrm{Cr}(\mathrm{VI})$ compounds is associated with a higher incidence of respiratory cancers. According to USEPA, the maximum contamination level (MCL) for $\mathrm{Cr}(\mathrm{VI})$ in domestic water supplies is $0.05 \mathrm{mg} / \mathrm{L}$ (Patterson, 1985). The permissible limit of hexavalent chromium for effluent discharge to inland surface water is $0.1 \mathrm{mg} / \mathrm{L}$. Wastewaters containing chromium must be treated to lower $\mathrm{Cr}(\mathrm{VI})$ to accepted limits before discharging that into the environment. There is increasing interest in the development of new processes for removal of heavy metals from wastewaters.

Improper management of waste plant biomass is contributing toward climate change, water and soil contamination, and local air pollution. There are advantages to use waste biomass especially agriculture waste to extract valuable chemicals. Considerable efforts are being made by the scientific community to convert plant wastes into a material resource. This effort would reduce the costs for waste disposal and would generate the revenue from the sale of the recovered materials. The waste biomass from seasonal ornamental plants is not the lucrative options for this purpose; however, it could be used as adsorbents for wastewater treatment. Biosorption of heavy metals from aqueous solutions is a relatively new process that has proven very promising in the removal of contaminants from potable water/aqueous effluents. The major advantage of biosorption technology is its effectiveness in reducing the concentration of heavy metal ions from dilute aqueous solutions to very low levels. Biosorption utilizes low-cost abundant raw materials and is an environmental friendly process (Fiol et al. 2008; Prabhakaran et al. 2009; Gupta et al. 2010). Different biomaterials have been used for removal of chromium which includes phyto-materials, industrial byproducts, and agricultural waste. Biosorption represents a sorption process that involves the transfer of metal ion from a bulk fluid to a surface. This process involves a solid-phase sorbent and a liquid phase containing dissolved species to be sorbed. It is a fast reversible reaction of the heavy metals with the biomass matrix (Pehlivan et al. 2012). Many inexpensive materials have been used for chromium removal (Nameni et al. 2008; Shah et al. 2009; Zvinowanda et al. 2009; Pehlivan et al. 2012). Various studies reported that biosorption capacities of various materials depend on their types, contact time, solution $\mathrm{pH}$, temperature, material dosage, etc. (Farooq et al. 2010). In our earlier studies, we have used PPBM for the removal of lead and cadmium (Dubey and Shiwani 2012; Dubey et al. 2013).

The purpose of the present study was to evaluate the potentiality of use of Portulaca plant biomass (PPBM), as a low-cost biosorbent for removal of $\mathrm{Cr}(\mathrm{VI})$ ions from aqueous solution. This material is completely chemical free, green and environment friendly. In the present work, batch experiments were conducted to investigate the effects of variables such as contact time, $\mathrm{pH}$, initial metal ion concentration and PPBM dose on $\mathrm{Cr}(\mathrm{VI})$ removal. Two kinetic models were used to correlate the experimental data. Two different isotherm equations were tested. Thermodynamic parameters were also studied. Present study is an attempt to try a method which is rather simple, costeffective and suitable for application in small-scale industries.

This work was done at MMH College, Ghaziabad, India, and was completed in May 2012.

\section{Materials and methods}

The chemicals used for this study were of analytical reagent grade and procured from the standard sources. The de-ionized water was used in all the experiments.

Preparation of stock solution

Stock solution was prepared by dissolving $1,000 \mathrm{mg}$ of potassium dichromate (Merck) in one liter of de-ionized water; the stock solution was diluted and used for different concentrations required for the experiments. $1 \mathrm{~N} \mathrm{HCl} / 1 \mathrm{~N}$ $\mathrm{NaOH}$ was used to obtain different $\mathrm{pH}$ values for the different experiments. 
Preparation of biosorbent

Portulaca is an herbaceous weed that can be found growing in wild and cultivated almost everywhere. It has smooth, reddish, mostly prostrate stems and alternate leaves clustered at stem joints and ends. Phytochemical screening of plant revealed the presences of many biologically active compounds such as alkaloids, carbohydrates, flavonoids, glycoside, amino acids, proteins, steroids, saponins, fixed oils, tannins and phenolic compounds (Kokate 1986; Harbone 1998). Owing to the presence of many functional groups, this plant material can be used as good biosorbent for removal of cations and anions from aqueous solutions (Pehlivan et al. 2012; Volesky 2007).

Portulaca can be found growing in almost any unshaded area; plant was collected from the local gardens. The collected material (stem and leaves) was washed exhaustively with water and finally with de-ionized water to remove dirt and particulate material from their surface. Material was sun-dried for 10 days, and then in microwave for about $30 \mathrm{~min}$ in a LG-make domestic microwave oven having temperature range $40-100{ }^{\circ} \mathrm{C}$ (Magnetrons are set at a frequency of $2,450 \mathrm{MHz}$ ) ( $\mathrm{LG}$ microwave appliance model no. MS-285SD; Korea) at $70{ }^{\circ} \mathrm{C}$. This dried material was then ground and sieved to get different size particles (200-1,000 $\mu \mathrm{m})$. No other chemical treatment was done. Unmodified powdered material of Portulaca plant biomass (PPBM) was kept in air-tight containers and used whenever required.

\section{Batch biosorption experiments}

A series of standard $\mathrm{Cr}(\mathrm{VI})$ test solutions $(50-500 \mathrm{mg} / \mathrm{L})$ were prepared by appropriate dilution of the stock $\mathrm{Cr}(\mathrm{VI})$ solution. Batch biosorption experiments were performed on thermo-stated orbital shaker at $100 \mathrm{rpm}$ in 250-ml flasks containing $200 \mathrm{ml}$ of test solution. Desired amount of biosorbent (0.1-1.5 gm) PPBM was added to these flasks. The effect of different operating conditions such as solution $\mathrm{pH}$, temperature, contact time, agitation speed, particle size, initial metal ion concentration, and dose of PPBM was investigated by varying only one of the operating conditions at one time, while others maintained constant. Optimum condition for each parameter was obtained by these experiments.

The residual concentration of $\mathrm{Cr}(\mathrm{VI})$ was measured by taking out the samples from the test solution after definite time intervals till the equilibrium was reached. The biosorbent was separated by filtration with Whatman filter paper number 41 followed by centrifugation at 3,000 rpm for $10 \mathrm{~min}$. The concentration of $\mathrm{Cr}(\mathrm{VI})$ in the filtrate was analyzed using an atomic absorption spectrophotometer (GBC Avanta). Absorption data obtained were used for different studies. Blank samples were also run under similar conditions. Each of the studies was conducted in triplicates, and the mean value (values ranges within \pm 2 ) was used for calculations.

\section{Kinetics experiments}

Test solution with different $\mathrm{Cr}(\mathrm{VI})$ ion concentration (50-500 $\mathrm{mg} / \mathrm{L})$ was taken using fixed amount of biosorbent. The initial $\mathrm{pH}$ of the solution was adjusted to 2 . Experiments were conducted at fixed temperature $\left(30^{\circ} \mathrm{C}\right)$ at 350-rpm agitation speed. Samples were withdrawn from the solution at definite time intervals until the equilibrium had reached. The residual chromium ion concentration was calculated as mentioned earlier. Data obtained were applied to two different kinetic equations.

\section{Results and discussion}

\section{Effect of $\mathrm{pH}$}

$\mathrm{pH}$ is an important controlling parameter in the biosorption process due to its influence on the surface properties of the biosorbent and the ionic form of the metal ion in solution (Mahajan and Sud 2011). Aqueous-phase pH governs the speciation of metals and also the dissociation of active functional sites present on the biosorbent (Azouaoua et al. 2010; Malkoc et al. 2006). Hence, metal sorption is critically linked with $\mathrm{pH}$. Not only different metals show different $\mathrm{pH}$ optima for their biosorption, but may also vary from one kind of biomass to the other (Ucun et al. 2002). Optimum $\mathrm{pH}$ is significant since $\mathrm{pH}$ affects not only the surface charge of biosorbent, but also the degree of ionization during reaction. In order to determine the optimum $\mathrm{pH}$ for maximum removal efficiency, experiments were carried out in the $\mathrm{pH}$ range $1-5$. $\mathrm{Cr}(\mathrm{VI})$ ion precipitates at higher $\mathrm{pH}$; therefore, higher $\mathrm{pH}$ values were not tested. Experiments were conducted by varying metal ion concentration from 50-500 mg/L, PPBM dose $0.5 \mathrm{gm}$, contact time $60 \mathrm{~min}$, and the $\mathrm{pH}$ was adjusted in the range $1-5$. The results of adsorption of $\mathrm{Cr}(\mathrm{VI})$ ions are shown in Fig. 1, which showed that biosorption decreased with increase in $\mathrm{pH}$. The similar trend is reported by many others (Ucun et al. 2002; Mahajan and Sud 2011). The optimum pH was found to be 2 and used for all further experiments.

At lower $\mathrm{pH}$ values, the surface of the biosorbents is surrounded by hydronium ions, which enhance the $\mathrm{Cr}(\mathrm{VI})$ interaction with binding sites of the biosorbents by greater attractive forces. However, at higher $\mathrm{pH}$, the overall surface charge on the biosorbents became negative and sorption of $\mathrm{Cr}(\mathrm{VI})$ decreased. In aqueous phase, $\mathrm{Cr}(\mathrm{VI})$ may exist in different anionic forms, such as chromate $\mathrm{CrO}_{4}{ }^{2-}$, 
Fig. 1 Effect of $\mathrm{pH}$ on biosorption $\left(\right.$ Temp $=30^{\circ} \mathrm{C}$, PPBM dose $=0.5 \mathrm{gm}$, Contact time $60 \mathrm{~min}$ )

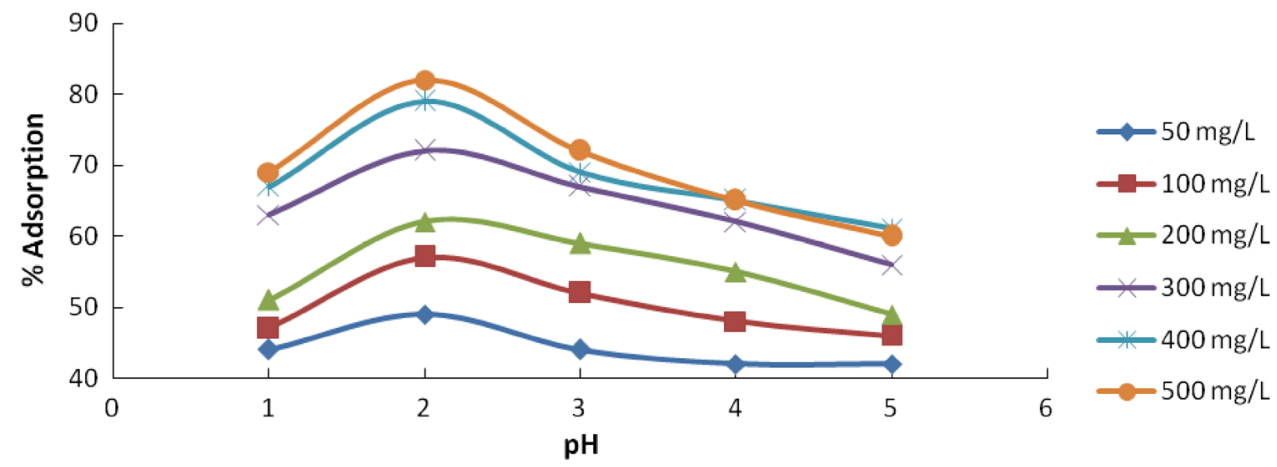

Fig. 2 Effect of particle size on biosorption $\left(\mathrm{Temp}=30^{\circ} \mathrm{C}\right.$, $\mathrm{pH}=2$, PPBM dose $0.5 \mathrm{gm}$, Contact time $=60 \mathrm{~min}, \mathrm{Cr}(\mathrm{VI})$ conc $=100 \mathrm{mg} / \mathrm{L}$ )

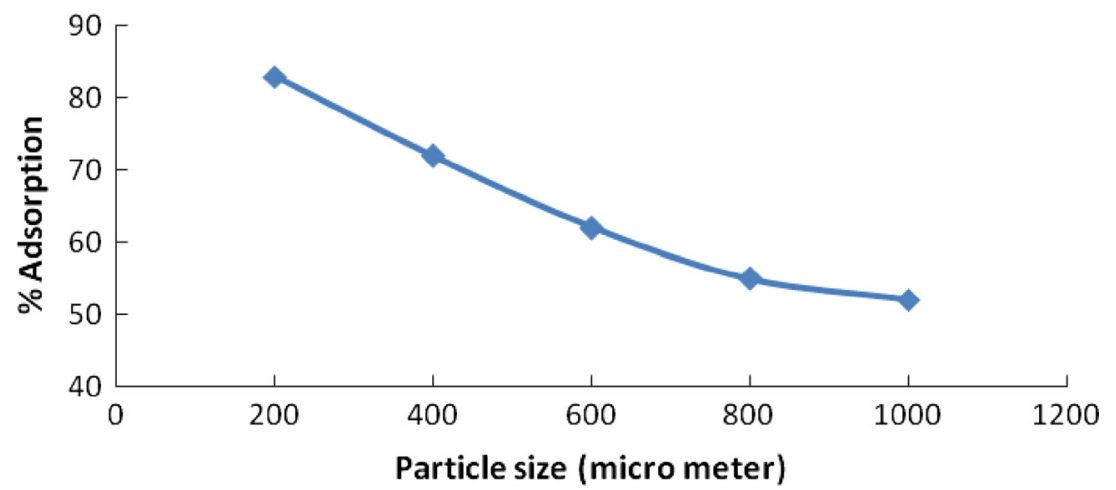

dichromate $\mathrm{Cr}_{2} \mathrm{O}_{7}{ }^{2-}$, or hydrogen chromate $\mathrm{HCrO}_{4}{ }^{-}$. The dominance of particular species depends on $\mathrm{pH}$. (Dakiky et al. 2002). In the $\mathrm{pH}$ range above 6.5 , the dominant species is $\mathrm{CrO}_{4}{ }^{2-}$ ions. In $\mathrm{pH}$ range $0-6.5$, mainly $\mathrm{HCrO}_{4}{ }^{-}$ and $\mathrm{Cr}_{2} \mathrm{O}_{7}{ }^{2-}$ are predominant (Dean and Tobin 2009). Acid chromate ion species $\mathrm{HCrO}_{4}{ }^{-}$is mainly present at lower $\mathrm{pH}$, which gets converted to other forms as the $\mathrm{pH}$ increases.

At lower $\mathrm{pH}$ due to protonation, the surface of the biosorbent becomes positively charged. Protons can easily coordinate with the functional groups present on the surface of the biosorbent. Binding of anionic $\mathrm{Cr}(\mathrm{VI})$ species increases with the increase in positive surface charge of the biosorbent, resulting in higher biosorption at lower $\mathrm{pH}$ values. As the $\mathrm{pH}$ increases, the hydrogen ion concentration decreases, and the surface charge of the biosorbent becomes negative which prevents the sorption of negatively charged chromium ion species. This explains the decrease in the biosorption of chromium(VI) ions at higher pH values (Pehlivan et al. 2012).

\section{Effect of particle size}

To find out the effect of particle size of biosorbent on the biosorption of chromium ions, experiments were conducted with fixed initial concentration $100 \mathrm{mg} / \mathrm{L}, \mathrm{pH} 2$, $150 \mathrm{rpm}$ for $60 \mathrm{~min}$, at $30{ }^{\circ} \mathrm{C}$ and biosorbent dose $0.5 \mathrm{gm}$ with particle size varying from 200 to $1,000 \mu \mathrm{m}$. Result shown in Fig. 2 indicates that biosorption was higher for smaller particle size. It was observed that the percentage of biosorption decreases with increased particle size. This may be because biosorption is a surface phenomenon; the smaller particle sizes offered comparatively larger surface area available, and hence, higher adsorption occurs at equilibrium. Similar trend is reported by others also (Nadeem et al. 2009). Since $\leq 200-\mu \mathrm{m}$-sized PPBM particles resulted in higher uptake of $\mathrm{Cr}(\mathrm{VI})$ ions from aqueous solution, it was subsequently used in all biosorption experiments.

\section{Effect of agitation speed}

Experiments were carried out by taking fixed chromium ion concentration $100 \mathrm{mg} / \mathrm{L}$, adsorbent dose $0.5 \mathrm{gm}, \mathrm{pH} 2$, for $60 \mathrm{~min}$ at $30^{\circ} \mathrm{C}$, with varying agitation speed $(50-350 \mathrm{rpm})$. The effect of agitation speed on the adsorption of chromium ions is shown in Fig. 3. As agitation speed increased, adsorption capacity of PPBM also increased from 59 to $83 \%$. This effect may be attributed to the decrease in boundary layer thickness around the biosorbent particles that results from increasing the degree of mixing (Saikaew and Kaewsam 2010). Results may be correlated with the fact that with the increase in agitation speed, the diffusion of ions toward the surface of the biosorbents improves. Agitation speed of $350 \mathrm{rpm}$ was fixed for further experiments. 
Fig. 3 Effect of agitation speed on biosorption

$\left(\mathrm{Temp}=\left(30^{\circ} \mathrm{C}\right), \mathrm{pH}=2\right.$, PPBM dose $0.5 \mathrm{gm}, \mathrm{Cr}$ ion conc $=100 \mathrm{mg} / \mathrm{L}$ )
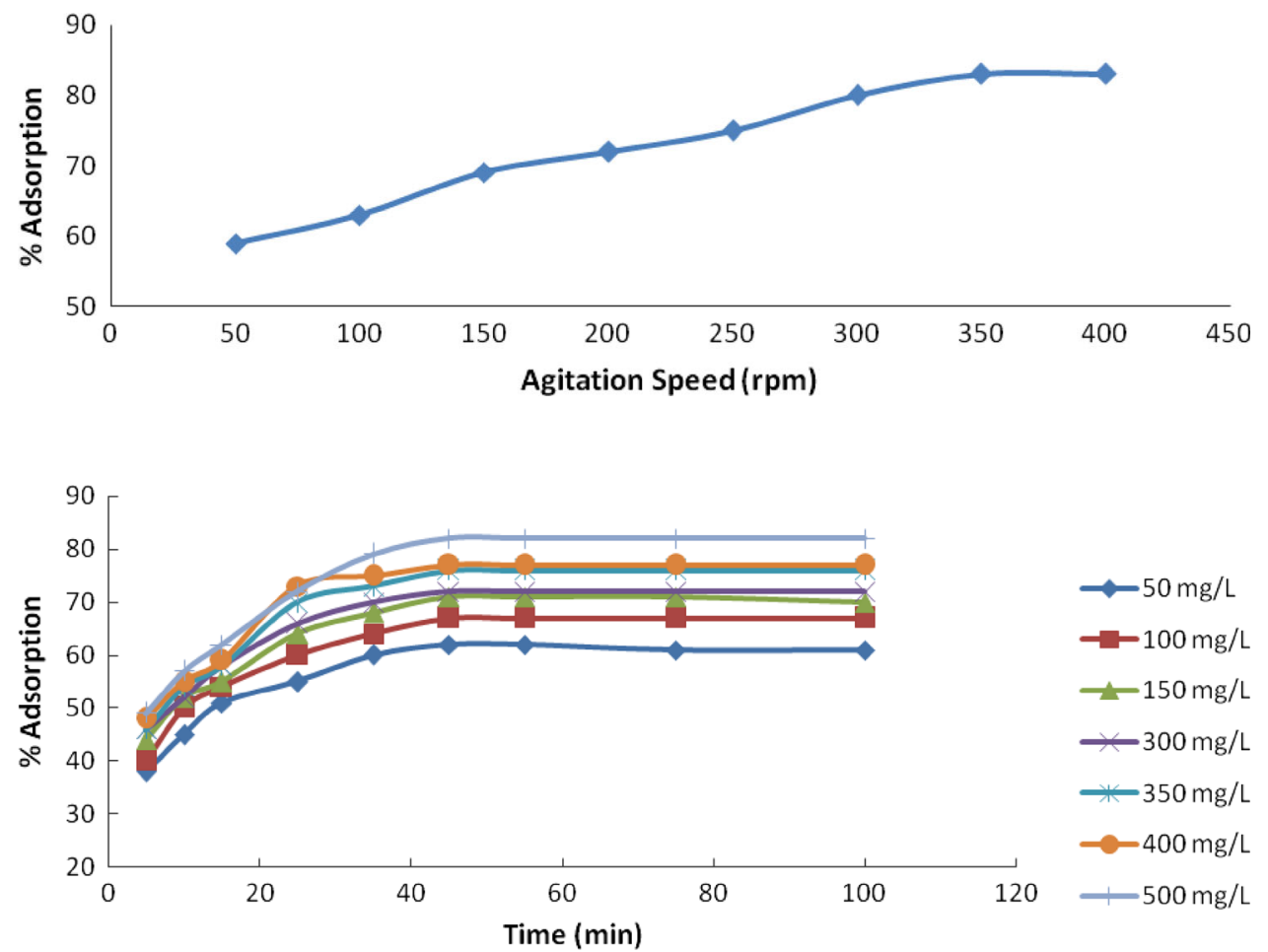

Time ( $\mathrm{min})$
Fig. 4 Effect of contact time and $\mathrm{Cr}(\mathrm{VI})$ ion concentration on biosorption $\left(\mathrm{Temp}=\left(30^{\circ} \mathrm{C}\right)\right.$, $\mathrm{pH}=2$, PPBM dose $0.5 \mathrm{gm})$
Effect of contact time and different initial metal ion concentrations

Experiments were conducted by varying metal ion concentration from 50-500 mg/L, $0.5 \mathrm{gm}$ PPBM, at $\mathrm{pH} 2$, and contact time was varied from 5 to $100 \mathrm{~min}$. Results are given in Fig. 4; the plot shows no appreciable change in the $\mathrm{Cr}$ (VI) biosorption after $45 \mathrm{~min}$, and at that point, equilibrium was achieved. This time is taken as equilibrium time; it is one of the important parameter for economical water treatment system. Equilibrium time is shown to be independent of initial $\mathrm{Cr}(\mathrm{VI})$ ion concentration. The plot has initial curved portion followed by linear portion and a plateau representing the equilibrium. From the figure, it is apparent that biosorption increased with increase in contact time, and major biosorption occurred in initial $20 \mathrm{~min}$, and after that, it became slower and almost constant after 45 min. Initial rapid biosorption could be explained by instantaneous utilization of most of the easily available sites present on the surface of biosorbent.

As shown in the Fig. 4, biosorption increases with increase in the concentration from 50 to $500 \mathrm{mg} / \mathrm{L}$ and remained same after that. According to Baral, this may be due to increase in the number of chromium ions available for the biosorption in the aqueous solution. Higher initial metal ion concentration provide higher driving force to overcome all mass transfer resistances of the metal ions from/between the aqueous solution to the solid phase, resulting in higher probability of collision between $\mathrm{Cr}(\mathrm{VI})$ ions and active sorption sites (Baral et al. 2006). A higher initial concentration provides an important driving force to overcome all mass transfer resistances of the pollutant between the aqueous and solid phases, thus increasing the uptake (Aksu and Tezer 2005).

\section{Effect of temperature}

Experiments were done at three different temperatures 20, 30 and $40{ }^{\circ} \mathrm{C}$. The biosorption increases with increase in temperature. Equilibrium time remained same for all temperatures Fig. 5, indicating that equilibrium time was independent of temperature. Results also indicate that biosorption was endothermic in nature. Increase in temperature favors the chromium ions transport within the pores of biosorbent (El-Shafey 2005). This trend might also be due to the increased number of biosorption sites generated because of breaking of some internal bonds near the edge of active surface sites of biosorbent (Singh et al. 2005; Singh and Hasan 2005). Some authors do explain that temperature affects the kinetic energies of chromium ions. At lower temperature, the kinetic energy remains low and increase in temperature increases the mobility of the ions (Malkoc et al. 2004; Malkoc and Nuhoglu 2007).

\section{Effect of biosorbent dose}

Experiments were conducted by taking optimum values for all other parameters already evaluated; only amount of 
Fig. 5 Effect of temperature on biosorption $(\mathrm{pH}=2$, PPBM dose $0.5 \mathrm{gm} \mathrm{Cr}$ ion conc $=100 \mathrm{mg} / \mathrm{L}$ )
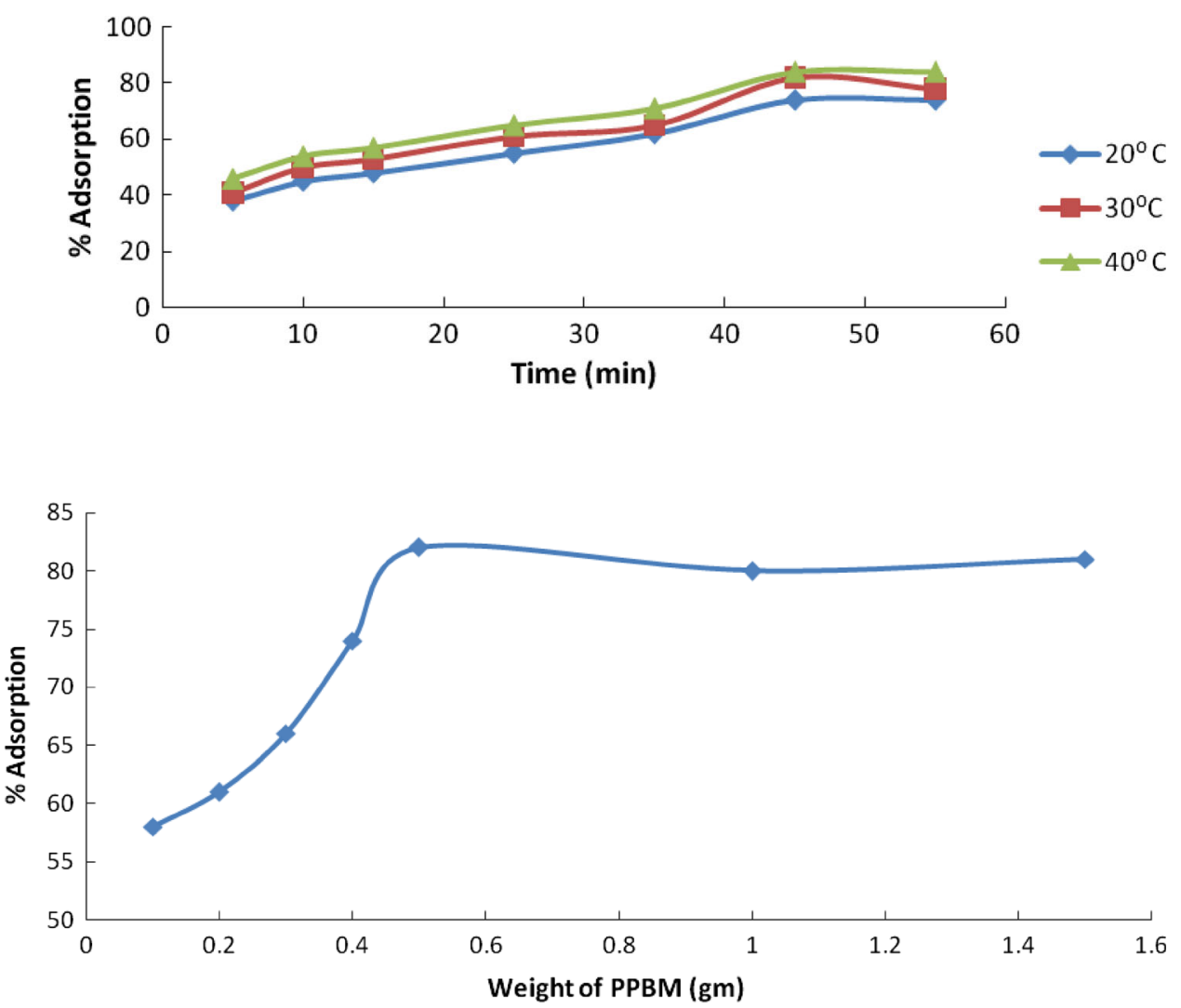

Fig. 6 Effect of biosorbent dose on biosorption $\left(\mathrm{Temp}=\left(30^{\circ} \mathrm{C}\right), \mathrm{pH}=2, \mathrm{Cr}\right.$ ion conc $=100 \mathrm{mg} / \mathrm{L}$ ) biosorbent was varied from 0.10 to $1.20 \mathrm{gm}$. Results clearly indicate the increase in the biosorption with increase in the dose till the dose was $0.5 \mathrm{gm}$ and remained almost constant after that (Fig. 6). This trend in removal was probably because the optimum amount of biosorbent in the experimental solutions caused a larger amount of $\mathrm{Cr}$ particles to aggregate and settle. However, more than one optimum amount of biosorbent, the solution would cause the aggregated particle to re-disperse and would also disturb particle settling. Results can be correlated with earlier studies (Pehlivan et al. 2012).

\section{Biosorption kinetics}

Kinetic experiments were conducted to evaluate the rate of the adsorption process and to examine the potential ratecontrolling steps. Kinetic models were applied to the complete range of contact time, for different initial metal ion concentrations of chromium ions. Experimental data were analyzed for pseudo-first-order and pseudo-secondorder kinetic models. Lagergren pseudo-first-order model assumes that the rate of occupation of sorption sites is proportional to the number of unoccupied sites (Cruz et al. 2004; Antunes et al. 2003), i.e., the rate of change of solute uptake with time is directly proportional to the difference in the saturation concentration and the amount of solid uptake with time. The general form of this model is expressed as

$\frac{\mathrm{d} q_{t}}{\mathrm{~d} t}=k_{1}\left(q_{\mathrm{e}}-q_{t}\right)$

where $q_{\mathrm{e}}$ and $q_{t}$ are amount of metal ion $(\mathrm{mg} / \mathrm{g})$ at time $\mathrm{t}$ and at equilibrium, respectively. $k_{1}$ is the rate constant of pseudo-first-order adsorption. Integrated form of equation is

$\frac{q_{t}}{q_{\mathrm{e}}}=1-\mathrm{e}^{\left(-k_{1} t\right)}$ or $\log \left(q_{\mathrm{e}}-q_{t}\right)=\log q_{\mathrm{e}}-\frac{k_{1} t}{2.303}$

Linear plot of $\log \left(q_{\mathrm{e}}-q_{t}\right)$ versus $t$ shows the applicability of pseudo-first-order kinetic model (Lagergren 1898; Ho and McKay 1998; Ho and McKay 1999). The rate constant $k_{1}$ and equilibrium amount of metal ion $q_{\mathrm{e}}$ can be obtained from the slope and the intercept of plot (Fig. 7). Correlation coefficient for the pseudo-first order was 0.886 . The calculated value of $k_{1}$ and $q_{\mathrm{e}}$ was $0.057 \mathrm{~min}^{-1}$ and $114.78 \mathrm{mg} / \mathrm{g}$, respectively.

The pseudo-second-order model (Ho and McKay 1999) is based on sorption capacity of solid phase.

$\frac{\mathrm{d} q_{t}}{\mathrm{~d} t}=k_{2}\left(q_{\mathrm{e}}-q_{t}\right)^{2}$

where $k_{2}$ is rate constant of pseudo-second-order adsorption $(\mathrm{g} / \mathrm{mg} / \mathrm{min})$. Integrated linear form of equation is 
Fig. 7 Pseudo-first-order kinetics plots for the biosorption ( $\mathrm{pH}=2, \mathrm{Cr}$ ion conc $=100 \mathrm{mg} / \mathrm{L}$, PPBM dose $0.5 \mathrm{gm})$
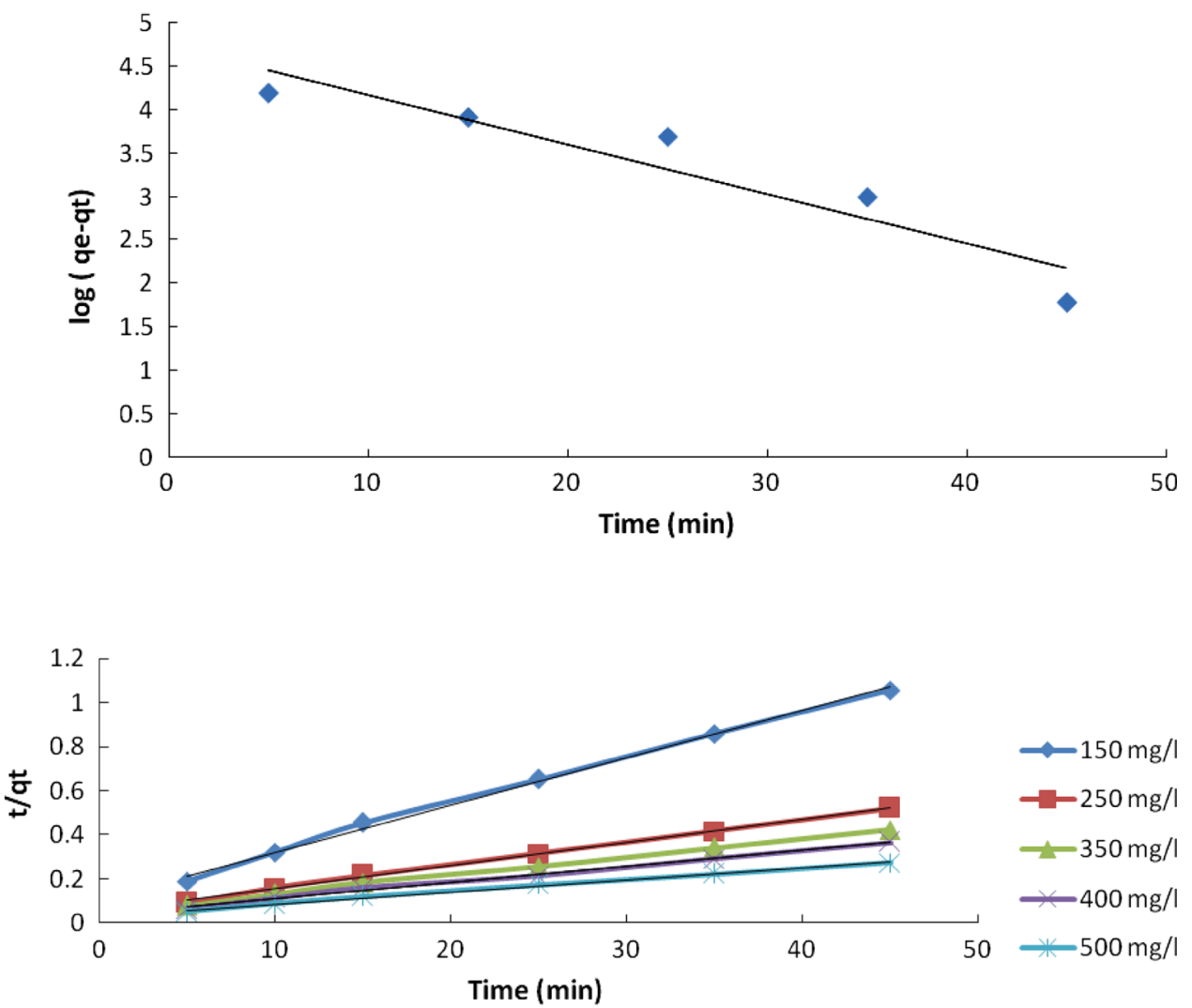

Fig. 8 Pseudo-second-order kinetics plots for adsorption at different chromium ion concentrations $(\mathrm{pH}=2, \mathrm{Cr}$ ion conc $=100 \mathrm{mg} / \mathrm{L}, \mathrm{PPBM}$ dose $0.5 \mathrm{gm})$ $\frac{t}{q_{t}}=\frac{1}{k_{2} q_{\mathrm{e}}^{2}}+\frac{t}{q_{\mathrm{e}}}$

This is the linear form of Ho second-order model. The plot of $t / q_{t}$ versus $t$ (Fig. 8) shows the kinetic data of adsorption of chromium ions on adsorbent. The good fit of kinetic data in second-order rate expression shows excellent linearity with high correlation coefficient $R^{2}$. The rate constant $k_{2}$ and equilibrium amount of metal ion $q_{\mathrm{e}}$ can be obtained from the slope and the intercept of plot (Fig. 8).

The value of $k_{2}, q_{\mathrm{e}}$ was calculated as $0.187 \mathrm{~g} / \mathrm{mg} / \mathrm{min}$, $31.15 \mathrm{mg} / \mathrm{g}$. The correlation coefficient for the pseudosecond order was 0.996. The kinetic plots of $t / q_{t}$ versus $t$ at different metal ion concentrations are presented in Fig. 8 which shows relationship is linear; and high value of correlation coefficient explains that the process follows the pseudo-second-order model in comparison with pseudofirst order.

\section{Biosorption isotherms}

The adsorption isotherm indicates distribution of metal ions between the liquid phase and the solid phase at equilibrium. Relationship between adsorbent and sorbate at equilibrium along with maximum sorption capacity can be evaluated by sorption isotherm model (Langmuir 1918). The analysis of the isotherm data by applying them to different isotherm models is an important step to find the suitable model that can be used for design purpose. Langmuir and Freundlich isotherm are widely used (Pehlivan et al. 2006). In the present work, these two isotherms were studied. An adsorption isotherm is characterized by certain constants; their values express the surface properties and affinity of the adsorbent.

The Langmuir expression is valid for monolayer adsorption on to a surface with finite number of identical sites (homogenous) without any interaction between adsorbed ions. The isotherm describes that adsorption at one site does not affect adsorption at an adjacent site. It provides information on uptake capabilities and reflects the usual equilibrium process behavior. The Langmuir expression is given by

$\frac{1}{Q_{\mathrm{e}}}=\frac{1}{q b C_{\mathrm{e}}}+\frac{1}{q}$

where $Q_{\mathrm{e}}=\mathrm{Cr}(\mathrm{VI})$ ions concentration at equilibrium $(\mathrm{mg} / \mathrm{g}), q=$ maximum metal uptake per unit mass of PPBM (mg/g) adsorption capacity, $b=$ Langmuir constant (L) related to energy of sorption, and $C_{\mathrm{e}}=$ Concentration of $\mathrm{Cr}(\mathrm{VI})$ ions in aqueous phase. 
Fig. 9 Langmuir adsorption isotherm $(\mathrm{pH}=2, \mathrm{Cr}$ ion conc $=100 \mathrm{mg} / \mathrm{L}$, PPBM dose $0.5 \mathrm{gm})$

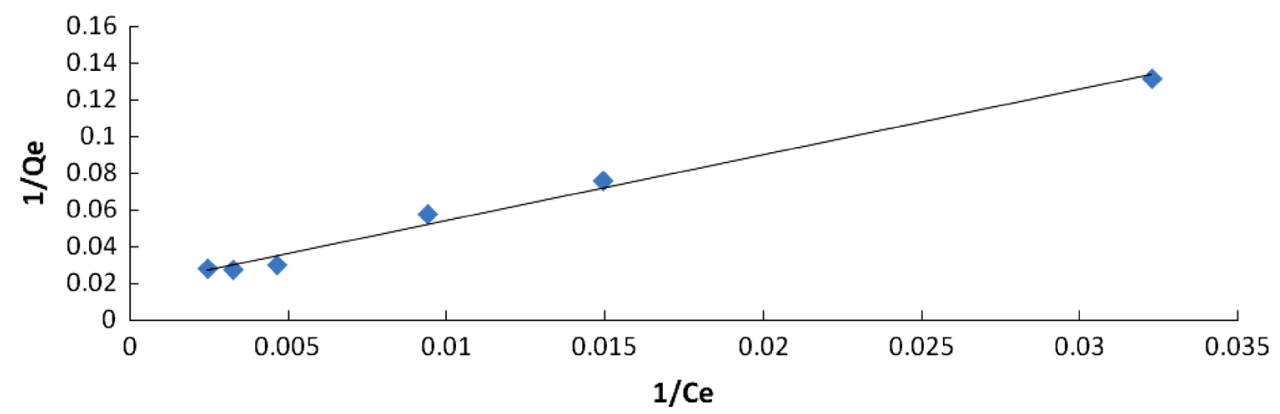

Fig. 10 Freundlich adsorption isotherm $(\mathrm{pH}=2, \mathrm{Cr}$ ion conc. $=100 \mathrm{mg} / \mathrm{L}$, PPBM dose $0.5 \mathrm{gm})$

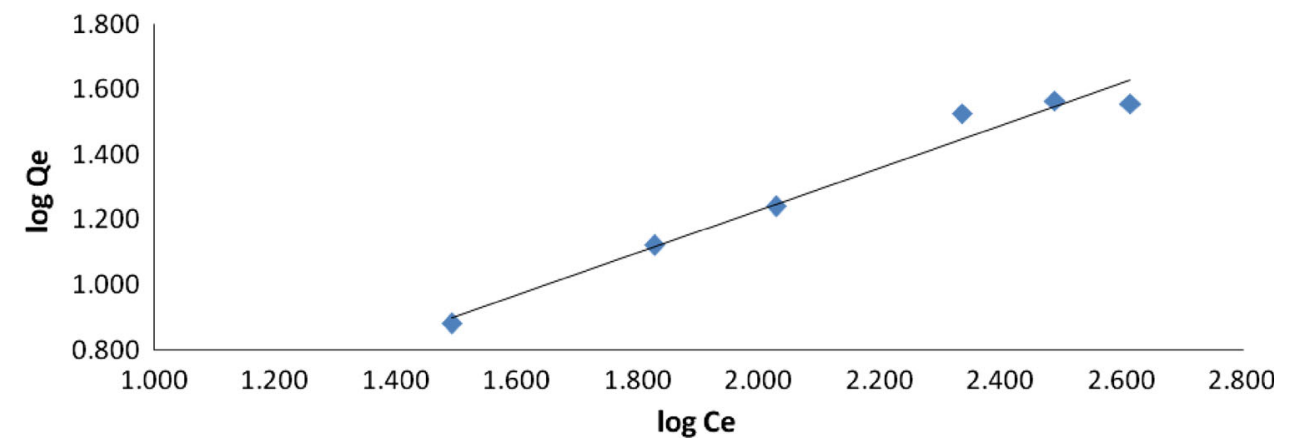

Here $b$ reflects quantitatively the affinity between the PPBM and $\mathrm{Cr}(\mathrm{VI})$ ions. The values of $\mathrm{q}$ and $b$ are the characteristics of the Langmuir model. They can be determined by linearizing above equation.

A plot of $1 / Q_{\mathrm{e}}$ versus $1 / C_{\mathrm{e}}$ gives a straight line of slope $1 / q b$ and intercept $1 /(q)$. The value of $Q_{\mathrm{e}}$ is given from the following equation:

$Q_{\mathrm{e}}=\left(C_{i}-C_{\mathrm{e}}\right) /(m / v)$

where $C_{\mathrm{i}}=$ initial concentration of $\mathrm{Cr}(\mathrm{VI})$ ions in the solution $(\mathrm{mg} / \mathrm{L}), C_{\mathrm{e}}=$ concentration of $\mathrm{Cr}(\mathrm{VI})$ ions at equilibrium, $v=$ initial volume of $\mathrm{Cr}(\mathrm{VI})$ ions solution used $(\mathrm{L}), \mathrm{m}=$ mass of PPBM used $(\mathrm{g})$.

Figure 9 shows the compiled results for Langmuir isotherm. The result of regression analysis for calculating the parameters of Langmuir shows that $q$ is $54.945 \mathrm{mg} / \mathrm{g}$, and adsorption equilibrium constant is $0.005 \mathrm{~L} / \mathrm{mg}$.

The essential features of Langmuir isotherm can be expressed in terms of dimensionless constant called separation factor or equilibrium parameter $R_{\mathrm{L}}$, which is indicative of isotherm shape that predicts whether an adsorption system is favorable or unfavorable. $R_{\mathrm{L}}$ is defined by following equation

$R_{\mathrm{L}}=1 /\left(1+b C_{0}\right)$

where $b$ is Langmuir constant and $C_{0}$ is initial concentration of $\mathrm{Cr}(\mathrm{VI})$ ion. Value of $R_{\mathrm{L}}$ indicates the isotherm to be irreversible $\left(R_{\mathrm{L}}=0\right)$, favorable $\left(0<R_{\mathrm{L}}<1\right)$, linear $\left(R_{\mathrm{L}}=1\right)$, or unfavorable if $\left(R_{\mathrm{L}}>1\right)$. This factor was calculated for chromium ions and found to be 0.283 ; from this value, it is confirmed that PPBM is a desirable biosorbent for chromium.

The Freundlich expression is empirical equation based on adsorption on a heterogeneous surface and the exponential distribution of active sites and their energies and was used to estimate the adsorption capacity and intensity of metal ions toward the adsorbent.

Freundlich isotherm:

$Q_{\mathrm{e}}=\mathrm{K} C_{\mathrm{e}}^{1 / n}$

$\mathrm{K}=$ Freundlich constant, indicating the adsorption capacity, $n=$ Freundlich constant, indicating the adsorption intensity.

The above equation is rearranged in linear form to give:

$\log Q_{\mathrm{e}}=\log \mathrm{K}+1 / n \log C_{\mathrm{e}}$

where $\mathrm{K}$ and $\mathrm{n}$ are determined from the intercept and slope, respectively, from the plot of $\log Q$ e versus $\log C$ e. The constant $\mathrm{n}$ is an empirical parameter that varies with the degree of heterogeneity, and $\mathrm{KF}$ is a constant related to adsorption capacity. Value of $\mathrm{K}$ is $1.071 \mathrm{mg} / \mathrm{g}$, and value of $1 / \mathrm{n}$ is 0.649 . Result is represented in Fig. 10 .

The values of the parameters show that PPBM is a good biosorbent for the uptake of chromium ions from aqueous solution. The co-efficient of co-relation $\left(R^{2}\right)$ was found to be as high as 0.989 and 0.969 for Langmuir and Freundlich isotherm, respectively, for the adsorption of chromium ions. These results showed that the equilibrium biosorption data conformed well with both the isotherms; 
Table 1 Comparison of biosorption capacity of different biosorbents for chromium

\begin{tabular}{|c|c|c|}
\hline Biosorbent & $\begin{array}{l}\text { Biosorption } \\
\text { Capacity } \\
\text { (mg/g) }\end{array}$ & Reference \\
\hline Orange peel & 39.11 & Bellu et al. 2010 \\
\hline Rice hull & 3.20 & Bellu et al. 2010 \\
\hline Neem sawdust & 58.82 & $\begin{array}{l}\text { Vinodhini and Das } \\
2010\end{array}$ \\
\hline Mango sawdust & 37.73 & $\begin{array}{l}\text { Vinodhini and Das } \\
2010\end{array}$ \\
\hline Pine needles & 40.0 & $\begin{array}{l}\text { Hadjmohammadi } \\
\text { et al. } 2011\end{array}$ \\
\hline Osage Orange & 93.67 & Pehlivan et al. 2012 \\
\hline $\begin{array}{l}\text { Compost from Carnation } \\
\text { flower waste }\end{array}$ & 6.26 & Vargas et al. 2012 \\
\hline PPBM & 54.95 & Present study \\
\hline
\end{tabular}

however, higher value of $R^{2}$ indicates Langmuir as favorable model. Freundlich model was not altogether properly able to describe the relationship between the amount of sorbed metal ion and their equilibrium concentrations in the solution. Results are comparable with the other biosorbents used for the removal of chromium as mentioned in Table 1 .

Biosorption thermodynamics

Thermodynamic parameters, energy and entropy can be determined using equilibrium constant $(\mathrm{K})$ which is temperature dependent. These parameters are used to determine spontaneous nature of biosorption.

Temperature is an important parameter for the biosorption of metal ions, dealing with the thermodynamics of the biosorption process, since it is directly related to the kinetic energy of metal ions. A slight change in temperature should cause a change in the amount of metal removed or sorbed by the biosorbent. The change in temperature causes a change in thermodynamic parameters like $\Delta G^{0}$,
Table 2 Thermodynamic parameters at different temperatures

\begin{tabular}{llllll}
\hline $\begin{array}{l}\text { Temperature } \\
\left({ }^{\circ} \mathrm{K}\right)\end{array}$ & $\begin{array}{l}1 / \mathrm{T} * \\
1,000 \\
\left({ }^{\circ} \mathrm{K}\right)\end{array}$ & $\begin{array}{l}\text { Equilibrium } \\
\text { constant } \mathrm{K}\end{array}$ & $\begin{array}{l}\Delta G \\
(\mathrm{KJ} / \\
\mathrm{mole})\end{array}$ & $\begin{array}{l}\Delta H \\
(\mathrm{KJ} / \\
\mathrm{mole})\end{array}$ & $\begin{array}{l}\Delta S \\
(\mathrm{KJ} / \\
\mathrm{mol})\end{array}$ \\
\hline 293 & 3.41 & 3.35 & -2.943 & 17.2 & 0.068 \\
303 & 3.30 & 4.56 & -3.819 & & \\
313 & 3.19 & 5.25 & -4.315 & & \\
\hline
\end{tabular}

$\Delta H^{0}$ and $\Delta S^{0}$. These parameters contribute to understand the sorption mechanism. The changes in free energy $\left(\Delta G^{0}\right)$, enthalpy $\left(\Delta H^{0}\right)$ and entropy $\left(\Delta S^{0}\right)$ associated with the adsorption were determined using following equations:

$\Delta G^{0}=-R T \ln \mathrm{K}$

where $R$ is universal gas constant $(8.314 \mathrm{~J} / \mathrm{mol} / \mathrm{K})$ and $\mathrm{T}$ is absolute temperature (K). The equilibrium constant may be defined as

$\mathrm{K}=C_{\mathrm{Ae}} / C_{\mathrm{e}}$

where $C_{\mathrm{Ae}}$ and $C_{\mathrm{e}}$ are the equilibrium concentration $(\mathrm{mg} / \mathrm{L})$ of the metal ions on the adsorbent and in the solution, respectively.

$\Delta G^{0}=\Delta H^{0}-T \Delta S^{0}$

where $\Delta G^{0}$ is the change in free energy, $\mathrm{kJ} / \mathrm{mol}, \Delta H^{0}$ the change in enthalpy, $\mathrm{kJ} / \mathrm{mol}$ and $\Delta S^{0}$ is the change in entropy, $\mathrm{kJ} / \mathrm{mol}$.

$\log \mathrm{K}=\frac{\Delta S^{0}}{2.303 R}-\frac{\Delta H^{0}}{2.303 R T}$

When $\log \mathrm{K}$ is plotted against $1 / T$ (Van't Hoff plot) (Fig. 11), a straight is obtained from which $\Delta H^{0}$ and $\Delta S^{0}$ were calculated from the slope and intercept. The negative value of $\Delta G^{0}$ at different temperatures (Table 2) shows that process is spontaneous, and material used has higher affinity at higher temperatures. The positive value of $\Delta H^{0}$ indicates that biosorption of $\mathrm{Cr}(\mathrm{VI})$ on material is
Fig. 11 Van't Hoff plot (Temp $=20-40{ }^{\circ} \mathrm{C}, \mathrm{pH}=2$, $\mathrm{Cr}$ ion conc $=100 \mathrm{mg} / \mathrm{L}$, PPBM dose $0.5 \mathrm{gm}$ )

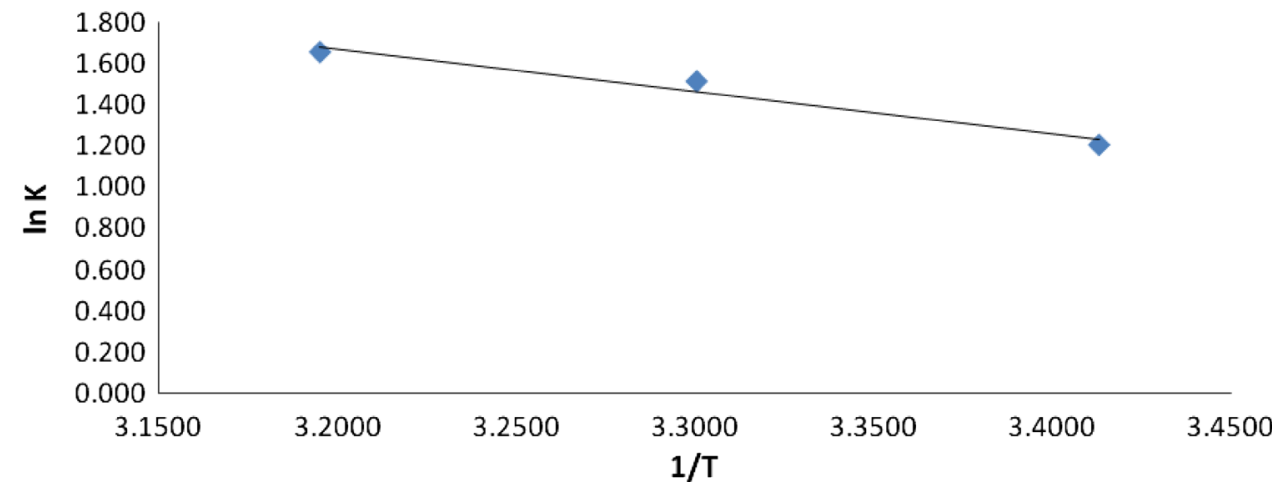


endothermic. The positive values of $\Delta S^{0}$ show that there is an increase in randomness at the solid-solution interface during the process. It also reflects the affinity of the biosorbent for chromium ions and also suggests some structural changes in biosorbent and chromium ions.

\section{Conclusion}

PPBM obtained from Portulaca Oleracea waste plant biomass proved to be an effective biosorbent for hexavalent chromium metal ion. PPBM can be used as an effective, efficient, cost-effective and environmentally safe biosorbent. The biosorption process is found to be dependent on various process parameters such as $\mathrm{pH}$, temperature, agitation speed biosorbent dose, and metal ion concentration. The percentage of biosorption increases with increase in metal ion concentration and biosorption dose. Maximum removal was at $\mathrm{pH} 2$, and equilibrium was achieved in only $45 \mathrm{~min}$. Biosorption increased with decreasing particle size of PPBM material. Kinetic studies showed that biosorption followed pseudo-second-order reaction. Experimental equilibrium data conformed well with both the isotherm models, but data were better represented by Langmuir model, and the sorption capacity of plant biomass was found to be $55.95 \mathrm{mg} / \mathrm{g}$. Thermodynamic parameters like $\Delta G^{0}, \Delta H^{0}$ and $\Delta S^{0}$ (Free energy change, enthalpy, and entropy) were also evaluated, and it was found that the biosorption was spontaneous and endothermic in nature. This study indicated that plant biomass could be used as an effective, efficient, costeffective and environmentally safe biosorbent for the treatment of chromium containing aqueous solutions. Portulaca plant biomass was found to be an effective and inexpensive adsorbent for removal of chromium(VI) from aqueous solution.

Acknowledgments Authors are thankful to the management of MMH College Ghaziabad for providing infrastructure support.

\section{References}

Aksu Z, Akpinar D (2001) Competitive biosorption of phenol and chromium(VI) from binary mixtures onto dried anaerobic sludge. Biochem Eng J 7(3):183-193. doi:10.1016/S1369703X(00)00126-1

Aksu Z, Tezer S (2005) Biosorption of reactive dyes on the green alga Chlorella vulgaris. Proc Biochem 40:1347-1361. doi:10.1016/j. procbio.2004.06.07

Antunes WM, Luna AS, Henriques CA, Costa ACS (2003) An evaluation of copper biosorption by brown seaweed under optimized conditions. Electron J Biotech 6(3):174-184
Azouaoua N, Sadaouia Z, Djaafri A, Mokaddema H (2010) Adsorption of cadmium from aqueous solution onto untreated coffee grounds: equilibrium, kinetics and thermodynamics. J Hazard Mater 184(1-3):126-134. doi:10.1016/j.hazmat.2010.08.014

Baniamerian MJ, Moradi SE, Noori A, Salahi H (2009) The effect of surface modification on heavy metal ion removal from water by carbon nanoporous adsorbent. Appl Surf Sci 256:1347-1354

Baral SS, Das SN, Rath P (2006) Hexavalent chromium removal from aqueous solution by adsorption on treated sawdust. Biochem Eng J 31:216-222. doi:10.1016/j.bej.2006.08.003

Bellu S, Sala L, González J, Garcí S, Frascaroli M, Blanes P, García J, Peregrin JS, Ferrón J, Atria A, Harada M, Cong C, Niwa Y (2010) Thermodynamic and Dynamic of Chromium Biosorption by Pectic and Lignocellulocic Biowastes. J Water Resour Prot 2:888-897. doi:10.4236/jwarp.2010.210106

Costa M (2003) Potential hazards of hexavalent chromate in our drinking water. Regul Toxicol Pharm 188:1-5

Cruz CCV, Da Costa ACA, Henriques CA, Luna AS (2004) Kinetic modeling and equilibrium studies during cadmium biosorption by dead Sargassum sp. Biomass. Biores Tech 91(3):249-257. doi:10.1016/S0960-8524(03)00194-9

Dakiky M, Khamis M, Manassra A, Mer'eb M (2002) Selective adsorption of chromium(VI) in industrial wastewater using lowcost abundantly available adsorbents. Adv Environ Res 6:533-540

Dean SA, Tobin JM (2009) Uptake of chromium cation and anions by milled peat. Resour Conserv Recycl 27:151-156

Dubey A, Shiwani S (2012) Adsorption of lead using a new green material obtained from Portulaca plant. Int J Environ Sci Tech 9(1):15-20. doi:10.1007/s13762-011-0012-8

Dubey A, Mishra A, Singhal S(2013) Application of dried plant biomass as novel low-cost adsorbent for removal of cadmium from aqueous solution. Int J Environ Sci Tech. doi:10.1007/ s13762-013-0278-0

El-Shafey EI (2005) Behaviour of reduction-sorption of chromium(VI) from an aqueous solution on a modified sorbent from rice husk. Water Air Soil Pollut 163:81-102

Farooq U, Kozinski JA, Khan MA, Athar M (2010) Biosorption of heavy metal ions using wheat based biosorbents-a review of the recent literature. Bioresour Technol 101(14):5043-5053. doi:10. 1016/j.biortech.2010.02.030

Fiol N, Escudero C, Villaescusa I (2008) Chromium sorption and $\mathrm{Cr}(\mathrm{VI})$ reduction to $\mathrm{Cr}(\mathrm{III})$ by grape stalks and yohimbe bark. Bioresour Technol 99(11):5030-5036. doi:10.1016/j.biortech. 2007.09.007

Gupta VK, Rastogi A, Nayak A (2010) Adsorption studies on the removal of hexavalent chromium from aqueous solution using a low cost fertilizer industry waste material. J Colloid Interface Sci 342:135-141

Hadjmohammadi MR, Salary M, Biparva P (2011) Removal of $\mathrm{Cr}(\mathrm{VI})$ from Aqueous Solution Using Pine Needles powder as a biosorbent. J App Sc In Environ Sanitation 6(1):1-13

Harbone JB (1998) Methods of extraction and isolation. Phytochemical Methods Chapman \& Hall, London, pp 60-66

Ho YS, Mckay G (1998) Sorption of dye from aqueous solution by peat. Chem Eng J 70(2):115-124

Ho YS, Mckay G (1999) Sorption of lead(II) ions on peat. Water Res 33(2):578-584

Kokate CK (1986) Practical pharmacognosy, 1st edn. Vallabh Prakashan, New Delhi

Lagergren S (1898) About the theory of so-called adsorption of solution substances. Handlinge 24(4):147-156 
Langmuir (1918) The adsorption of gases on plane surfaces of glass, mica and platinum. J Am Chem Soc 40(9):1361-1403

Mahajan G, Sud D (2011) Kinetics and equilibrium studies of Cr(VI) metal ion remediation by Arachis Hypogea shell: a green approach. Bioresour Technol 6(3):3324-3338

Malkoc CE, Nuhoglu-Diaz A, Colın-Cruz F, Urena-Nunez M, Romero-Romo M, Palomar-Pardav E (2004) Cr(VI) removal from wastewater using low cost sorbent materials: roots of Typha latifolia and ashes. Environ Technol 25(8):907-917

Malkoc CE, Nuhoglu Y, Dundar M (2006) Adsorption of chromium(VI) on pomace-an olive oil industry waste: batch and column studies. J Hazard Mater 138:142-151. doi:10.1016/j. jhazmat.2006.05.051

Malkoc CE, Nuhoglu Y (2007) Potential of tea factory waste for chromium(VI) removal from aqueous solutions: thermodynamic and kinetic studies. Sep Purif Technol 54(3):291-298. doi:10. 1016/j.seppur.2006.09.017

Nadeem R, Hanif MA, Mahmood A, Jamil MS, Ashraf M (2009) Biosorption of $\mathrm{Cu}(\mathrm{II})$ ions from aqueous effluents by blackgram bran (BGB). J Hazard Mater 168:1622-1625. doi:10.1016/j. jhazmat.2009.02.135

Nameni M, Alavi Moghadam MR, Arami M (2008) Adsorption of hexavalent chromium from aqueous solutions by wheat bran. Int J Environ Sci Tech 5(2):161-168

Park S, Jung WY (2001) Removal of chromium by activated carbon fibers plated with copper metal. Carbon Sci 2:115-121

Patterson JW (1985) Industrial wastewater treatment technology, 2nd edn. Butterorth Publisher, Stoneham, MA

Pehlivan E, Cetin S, Yanık BH (2006) Equilibrium studies for the sorption of zinc and copper from aqueous solutions using sugar beet pulp and fly ash. J Hazard Mater 135(1-3):193-199. doi:10. 1016/j.jhazmat.2005.11.049

Pehlivan E, Pehlivan E, Tutar Kahraman H (2012) Hexavalent removal of chromium by Osage orange. Food Chem 133(4):1478-1484. doi:10.1016/j.foodchem.2012.02.037

Prabhakaran SK, Vijayaraghavan K, Balasubramanian R (2009) Removal of $\mathrm{Cr}(\mathrm{VI})$ ions by spent tea and coffee dusts: reduction to $\mathrm{Cr}$ (III) and biosorption. Ind Eng Chem Res 48:2113-2117. doi:10.1021/ie801380h

Raji C, Anirudhan TS (1998) Batch Cr(VI) removal by polyacrylamide-grafted sawdust: kinetics and thermodynamics. Water Res 32:3772-3780. doi:10.1016/S0043-1354(98)00150-X

Rowbotham AL, Levy LS, Shuker LK (2000) Chromium in the environment: an evaluation of exposure of the UK general population and possible adverse health effects. J Toxicol and Environ Health 3(3): 145-178

Saikaew W, Kaewsam P (2010) Durian peel as biosorbent for removal of cadmium aqueous solution.J. Environ Res 32(1): $17-30$

Shah BA, Shah AV, Singh RR (2009) Sorption isotherms and kinetics of chromium uptake from wastewater using natural sorbent material. Int J Environ Sci Tech 6(1):77-90

Sheng PX, Tan LH, Chen JP, Ting YP (2004) Biosorption performance of two brown marine algae for removal of chromium and cadmium. J Disper Sc and Tech 25:679-686. doi:10.1081/DIS200027327

Singh KK, Rupainwar DC, Hasan SH (2005) Low cost biosorbent 'Maize Bran' for the removal of cadmium[II] from wastewater. J Ind Chem Soc 82:392-396
Singh KK, Hasan SH (2005) Removal of copper from wastewater using rice polish (rice bran). J Ind Chem Soc 82:374-375

Ucun H, Bayhan YK, Kaya Y, Cakici A, Algur OF (2002) Biosorption of chromium(VI) from aqueous solution by cone of Pinus sylvestris. Bioresour Technol 85:155-158

Vargas C, Brandao PFB, Agreda J, Castillo E (2012) Biosorption using compost: an alternative for removal of Chromium(VI) from aqueous solutions. Bioresour Technol 7(3):2711-2727

Vinodhini V, Das N (2010) Relevant approach to assess the performance of sawdust as adsorbent of chromium(VI) ions from aqueous solutions. Int J Environ Sci Tech 7(1):85-92

Volesky B (2007) Biosorption and me. Water Res 41(18):4017-4029

Zvinowanda CM, Okonkwo JO, Shabalala PN, Agyei NM (2009) A novel adsorbent for heavy metal remediation in aqueous environments. Int J Environ Sci Tech 6(3):425-434

\section{Weblink (Abstract)}

http://www.sciencedirect.com/science/article/pii/S0032959204002195 http://redalyc.uaemex.mx/src/inicio/ArtPdfRed.jsp?iCve=173314709003 http://www.sciencedirect.com/science/article/pii/S0304389410010307 http://www.sciencedirect.com/science/article/pii/S016943320901229X http://www.sciencedirect.com/science/article/pii/S1369703X06002014 http://www.SciRP.org/journal/jwarp

http://www.ncbi.nlm.nih.gov/pubmed/12668116

http://www.sciencedirect.com/science/article/pii/S0960852403001949

http://www.ingentaconnect.com/content/els/10930191/2002/0000000 6/00000004/art00079

http://cat.inist.fr/?aModele $=$ afficheN\&cpsidt $=1835624$

http://www.researchgate.net/publication/226685075

http://www.sciencedirect.com/science/article/pii/S0960852410003019

http://www.sciencedirect.com/science/article/pii/S096085240700747X

http://www.ncbi.nlm.nih.gov/pubmed/19896674

http://trisanita.org/jases/asespaper2011/ases01v6n1y2011.pdf

http://www.scielo.br/scieloOrg/php/reflinks.php?refpid=S0102-695X200 $800040000500011 \&$ pid=S0102-695X2008000400005\&lng=en

http://www.ingentaconnect.com/content/els/13858947/1998/0000007 0/00000002/art00076

http://www.ingentaconnect.com/content/els/00431354/1999/0000003 3/00000002/art00207

http://www.scielo.br/scieloOrg/php/reflinks.php?refpid=S0102-695X200 $800040000500012 \&$ pid $=$ S0102-695X2008000400005\&lng=en

http://dns2.asia.edu.tw/ ysho/YSHOEnglish/1000\%20WC/PDF/J\% 20Ame\%20Che $\% 20$ Soc $40, \% 201361 . p d f$

http://www.ncsu.edu/bioresources/BioRes_06/BioRes_06_3_3324

http://www.sciencedirect.com/science/article/pii/S0304389406005383 http://www.sciencedirect.com/science/article/pii/S1383586606003066 http://www.sciencedirect.com/science/article/pii/S0304389409003422 http://www.bioline.org.br/pdf?st08019

http://www.osti.gov/energycitations/product.biblio.jsp?osti_id=7253209 http://pubget.com/paper/pgtmp_82cebe922506cb811b0f84d11d737144 http://www.sciencedirect.com/science/article/pii/S0960852403003468

http://www.ncbi.nlm.nih.gov/pubmed/10911983

http://www.eric.chula.ac.th/jer-en/download/v32y2553/v32n1y2553/ ar2v32n1y2553.pdf

http://www.sid.ir/en/VEWSSID/J_pdf/92220090108.pdf

http://www.tandfonline.com/doi/abs/10.1081/DIS-200027327 
http://dns2.asia.edu.tw/ ysho/YSHO-English/Publications/PDF/J\% 20Haz\%20Mat152,\%20356.pdf

http://www.sciencedirect.com/science/article/pii/S096085240200086X

http://www.ncsu.edu/bioresources/BioRes_07/BioRes_07_3_2711_ Vargas_BAC_Biosorp_Compost_Cr6_Aq_Soln_2495.pdf
http://www.ijest.org/?_action=articleInfo\&article=379

http://www.bioline.org.br/pdf?st09047

http://biosorption.mcgill.ca/publication/PDFs/188-WR'07,41,4017-29bs\&me.pdf 